\title{
Orality and Capitalist Logic in the Music of Samba Schools (1)
}

\author{
Yuri Prado \\ Universidade de São Paulo (USP) \\ yuri_prado@yahoo.com.br
}

\begin{abstract}
One of the most striking features of the music of samba schools, the samba-enredo, is its high degree of formularity, manifested in the works of many composers from diverse epochs and stylistic tendencies. In this article, I intend to relate this phenomenon to the popular (oral) conscience model that still exists in the samba schools, and also to the fact that samba-enredo is embedded in a capitalist logic that ranges from the cultural industry in which it takes part to how works are chosen for performance in Carnival.
\end{abstract}

KEYWORDS: Samba schools, formularity, orality, culture industry

\section{Introduction}

Since their founding at the end of the 1920s, the samba schools of Rio de Janeiro, well-organized groups which parade every year in carnival, are institutions marked by a series of contradictions. These contradictions concern their negotiations with the government (the struggle for the schools to thrive amidst the ruling of governmental power), the valorization of their members' labour (some sectors have no wages while others are overpaid), financial management (public subsidies, private companies' sponsorship and even laundered money from Jogo do Bicho, an illegal gambling lottery), their social role (as a leisure space in deprived communities and as a celebrity showcase, once their parades are broadcast on the major network in Brazil, Rede Globo), and even their own discourse (claiming themselves as guardians of samba traditions while they strive for innovation, especially in the visual aspects of the parades).

The music produced by samba schools, the samba-enredo, is marked by a contradiction that, to a certain extent, runs through all those mentioned above: most of the time, it is a product of music making strongly marked by orality, while simultaneously fitting into the capitalistic logic of the cultural industry in which it takes part. In addition, each samba school has its own way of selecting the works 
presented in carnival. In this article, I examine how these two poles are formed and the role they play in the presence of a high amount of formularity in samba-enredo.

\section{Orality}

In his famous book Orality and Literacy, Walter Ong suggests the existence of a primary orality that is "of a culture totally untouched by any knowledge of writing or print", and a secondary orality, existing in the modern culture of high technology, mediated by "telephone, radio, television, and other electronic devices that depend for their existence and functioning on writing and print" (Ong 2002: 10-11). According to the author, despite the practical inexistence of a "pure" primary orality nowadays, it is still possible to identify ways of thinking in many contemporary cultures that somehow preserve this kind of orality. According to Ricardo Azevedo, this is precisely the case of the samba schools:

Beyond external interferences as well as commercial and political interests, samba schools can still be considered and described as essentially communitary, collective, affective, interested and spontaneously organized public spaces, where family, hierarchies, context (and religiosity) are mingled and synthesized in an admirable way. (...) It should be noted that, although traditional, they are located in big cities, are absolutely contemporary and included in modernity, even though, as all the evidence shows, they are the fruit of another model of consciousness (Azevedo 2013: 344, my translation).

According to Azevedo, the culture of samba is marked by a popular consciousness model, related to orality (opposed to the hegemonic, modern and educated model, related to writing), which is manifested not only as a form of socialization among the sambistas but also in the themes presented in their works:

Collective and communitary life, family hierarchies, religiosity and magic, overestimation of common sense, food, labour and money (the struggle for survival) as well as a deep connection with oral culture and its implications, have been and continue to be even nowadays subjects viscerally linked to samba (Azevedo 2013: 129, my translation).

It is noticeable that, in samba, the musical enculturation - the "immersion in the music and the musical practices of one's environment" (Green 2001: 5) — is often developed both through self-learning and an attentive observation of the older sambistas' music making. Take this observation from Tuninho Professor, a respected samba composer:

When I was a child I accompanied my brothers to samba. My brother Jorge had attended [the carnival group] Cacique de Ramos since he was a child, and he attended [the samba school] Imperatriz Leopoldinense when it still rehearsed in [the club] Paranhos. My brother-in-law, Trajano Russo, who is considered one of the greatest partideiros [samba improvisers] in Brazil and in Rio de Janeiro, would go there too and I also used to accompany them. I was always lurking, always waiting for an opportunity, listening to one, listening to another. Another brother-in-law, Denir Lobo, went there and along with them I began to meet, when I was still a child, composers of Imperatriz Leopoldinense who frequented a corner on which there was the bar called $\mathrm{EI}$ Fernando, which on Sundays promoted a samba with the people of Imperatriz Leopoldinense and people related to samba. As my brothers and brother-in- 
law also went there, I would go there and listen to them. I loved listening to them (Professor 2015, my translation).

In addition to learning the repertoire, it was common for the learning of musical instruments to take place at rodas de samba (samba meetings). According to the composer André Diniz, it is possible to see that even in the 1990s, when he began to compose sambas-enredo, the acquisition of knowledge occurred in these informal situations:

I joined [the football supporters club] Raça, from [the football team] Flamengo, and at the entrance door of Raça's head office there was a pagode [samba meeting]. So, I would see Bocão playing tan-tan [a cylindrical hand drum] and there was a boy named Marquinhos, who was Marquinhos do Banjo, a composer from [the samba school] União da Ilha, who played the banjo [a four-string instrument adapted and introduced in samba by Almir Guineto in the late 1970s], and I kept looking at them. Then I started learning to play the cavaquinho [a four-string Brazilian lute] (Diniz 2013, my translation).

Some composers spontaneously showed a predisposition to composing in their childhood; often these first attempts at composition were judged, generally rather rigorously, by their own family members:

I used to go down the hill to fetch some water and the kids would drum as they walked, singing sambas. So did I and here I am today. God bless that water can! (Katimba 2009, my translation).

My brother-in-law was a composer and he'd help me a lot, give me a lot of orientation, and I used to learn a lot from him. When I made bad stuff and showed him, he'd say: "It's shit". (...) I'd make those verses, sing them to him [and he would say]: "Oh, boy, that's so bad as it is (...) it needs a touch-up" (Guga 2013, my translation).

These statements confirm a fact pointed out by Azevedo (2013: 242) of the importance of "learning by doing", in opposition to theoretical learning through reading. In fact, most samba-enredo composers never had the chance to attend a music academy. Therefore, some of them only play percussion instruments, learned "in the streets" through the practice of samba, or play string instruments without great technical skill (2):

I'm a percussionist even to this day. I can't play string instruments. A chord on the cavaquinho or the guitar can be done, though. Anyone can do it, it's easypeasy. But I don't play the guitar. For you to say you play the guitar or the cavaquinho, you got to do it for real (Martinho da Vila 2014, my translation).

I play the guitar, but the basics of the ABC's. I'm not a guitarist. I play it, I do some stuff, it helps me in a few things, but I'm not a formal musician (Toninho Nascimento 2014, my translation).

There are sambistas who do not play any instrument and even so, or exactly for that reason, have reached a level of excellence as composers (3):

Even to this day I don't know a single musical note... I really can't learn it. Sometimes I try some beats on the tamborim [a small Brazilian frame drum] 
with my fingertips and even then, I think I am out tune [laughs] (Katimba 2009, my translation).

I never studied music. It's a native musicality. A lot of people find it odd that I do not play any instruments. Usually those who do not play any instrument make only lyrics or simple melodies. They find it odd that I make richer, more elaborate melodies without playing an instrument (Diego Nicolau 2015, my translation).

The notions of family and hierarchy are fundamental to understanding the popular consciousness model and, consequently, the samba schools. If there is a core group in the samba schools that expresses these notions, it is the composers' wing (ala dos compositores). For a long time, at least since before the construction of the Sambódromo (Sambadrome) in 1984 for the samba schools' parades, the composers' wing was an institution with its own rules, enjoying considerable organizational autonomy. For young composers, entry to this group signified maturity as samba musicians and belonging to the intellectual elite of the samba schools. Being admitted to a composer's wing, however, was not an easy task; as we've found from the statements by several composers, there was great rigour in the admission of new members, since many samba schools require candidates to pass a musical composition test:

Back in the day, you had to compose. You had to prove you were a composer. It was up to you, to improvise, to make [a samba] right there. They'd give you a subject and then you did like "My love let me down", or whatever, but one had to make it on the spot (Sabiá 2009, my translation).

Admission to a composers' wing didn't necessarily mean permission to take part in the internal samba-enredo contests, in which it is decided whose work is going to be sung in the parade. First, it was demanded that the new member went through a kind of internship:

When a composer joined a school, he could not compete in a samba-enredo contest. Today it's different: one comes in and composes a samba-enredo, just like that. In the past, one used to spend three years in the school only composing samba de quadra (4). It was an internship. I used to say I was inside the fence, just waiting for my turn (Guga 2013, my translation).

The importance of samba de quadra within the samba schools was immense. Presented on every social occasion, such as parties and rehearsals, it constituted the majority of the musical repertoire of a community, distinguishing it from others. As a platform for new talent, samba de quadra paved the way for samba-enredo composing:

Every school had the samba de quadra for one to fit in with the family, to learn that particular school's rhythm and its way of being. Nowadays, you don't need to compete, you come and go straight to samba-enredo composing (Portela 2009, my translation).

The way of living and learning within the samba schools described here may be one of the reasons for the presence of formularity in samba-enredo and, consequently, of a view of musical creation that strongly differs from the 
consciousness model based on writing, in which there's always a pursuit for originality (Azevedo 2013: 88).

According to Ong (2002: 24), "in an oral culture, knowledge, once acquired, had to be constantly repeated or it would be lost". Hence the importance of formulae: expressions modelled in such way they are of quick apprehension and memorization as well as being versatile enough to be used in a wide range of contexts. Thus, for the author, the manifestation of formularity in discursive practices in the contemporary world can be seen as residues of the oral model of thinking. Martha Tupinambá Ulhôa thinks likewise:

Urban popular music has many features of orality, such as short phrases, simple harmonic patterns, structural repetitions. That is, being transmitted orally and depending on biological memory to be passed on imposes some restrictions on popular music (Ulhôa 2008: 250, my translation).

Lars Lilliestam reminds us that the concept of formula may cover several parameters of music. Therefore, "we can speak of melodic formulae, chord sequences, rhythmic formulae, patterns of accompaniment ('grooves'), riffs, formulae for the construction of musical form, lyrical formulae, matrices for the construction of lyrics, etc." (Lilliestam 1996: 204). In samba, certain harmonic progressions tend to be rather recurrent, serving as the basis of musical composition even to composers who don't play any string instruments, which means they are deeply rooted in the sambistas' memories. For Carlos Almada, part of the spontaneity that typifies the making of music in a roda de samba is due to the predictability offered by such formulae:
It's often surprising to a musician "from outside" to be met with the great skill of samba guitar players and cavaquinho players to harmonize. Many times, in informal rodas, an unknown melody sung by some anonymous singer/composer is instantly harmonized - and adorned by intricate counterpoints in the lower strings of the seven-chord guitar, in a true improvisation. The huge experience of these instrumentalists, combined, obviously, with extremely accurate harmonic listening, allows them to - like a chess player anticipating his opponent's moves - almost foretell the direction a melodic line is going to take, instantly finding its appropriate chords. Such skill, which may seem like a mysterious phenomenon to "the laymen", is actually the result of vast personal experience among the sambistas along with (mostly) intuitive knowledge of numerous characteristic harmonic formulae in the genre (Almada 2012: 212, footnote, my translation).

In the case of samba-enredo, I was able to verify the composers' preference for one out of these harmonic formulae (Figure 1), which presents sixteen measures divided as follows: in the first four measures, the I scale degree is stated; in the following four ones, (5 to 12) there is a transition to II degree; the measures 9 to 12 state this new degree; finally, the last four phrases (13 to 16) bring back the I degree: 


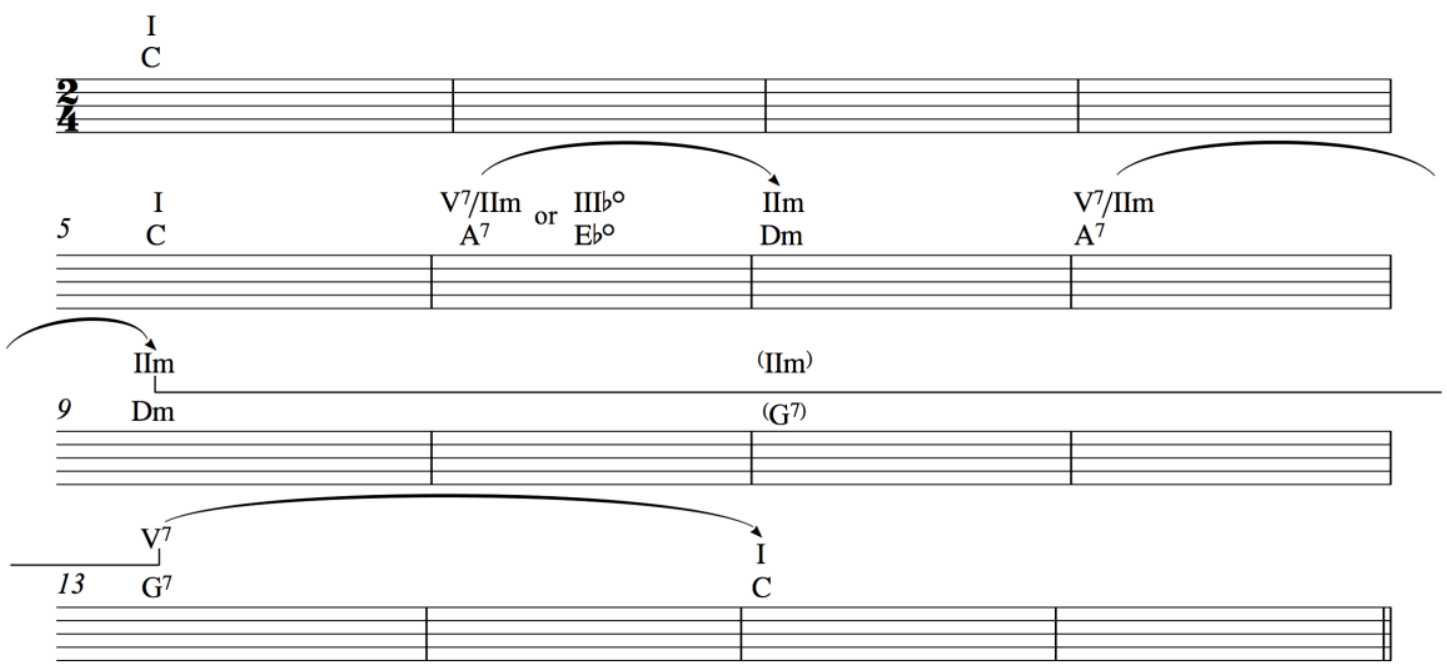

FIGURE 1. Samba-enredo harmonic formula

Concerning melodic formularity, the 1975 samba-enredo by Portela samba school, Macunaíma, herói da nossa gente (Figure 2), is a good example of the way it works:

"Macunaíma, herói de nossa gente", Portela, 1975 (David Corrêa / Norival Reis)

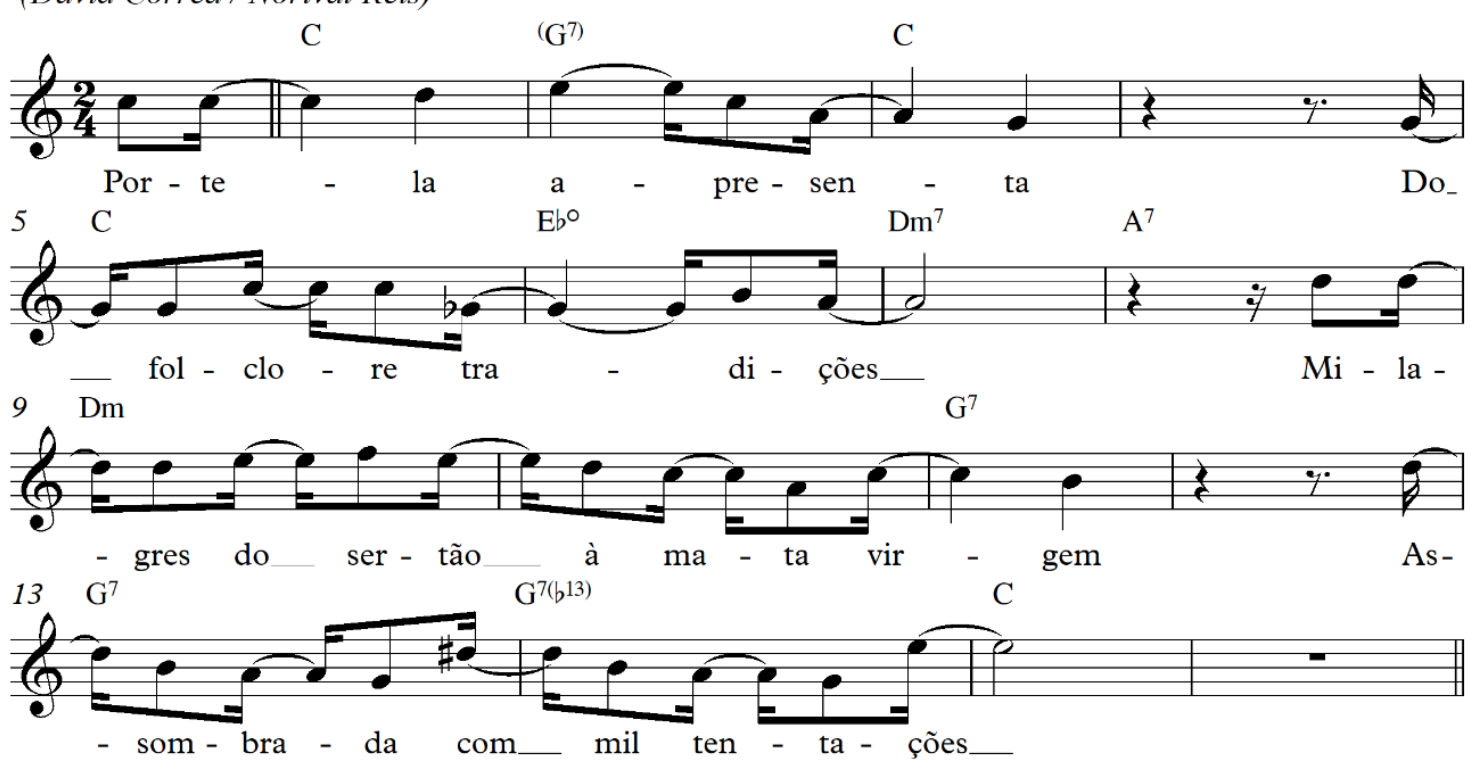

FIGURE 2. First sixteen measures of Macunaíma, herói de nossa gente (Portela, 1975)

Each of its four phrases (which follow, with some variation, the above-mentioned harmonic formula) are shared with other sambas (5). The first phrase, for instance, is quite similar to those of Lapa em três tempos (Portela, 1971), Das maravilhas do mar fez-se o esplendor de uma noite (Portela, 1981, composed by David Corrêa as well), Dos Jardins do Éden a Era de Aquarius (Vila Isabel, 1981), Se esta terra, se esta terra fosse minha (Vila Isabel, 1990) and Ouro escravo (Em Cima da Hora, 1969) (Figure 3): 
"Macunaima, herói de nossa gente", Portela, 1975

(David Corrêa / Norival Reis)

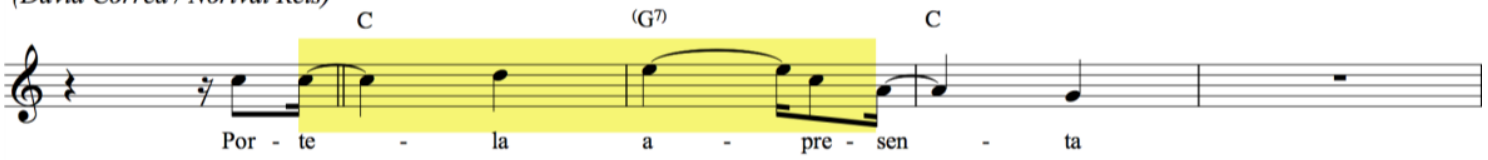

"Dos jardins do Éden à Era de Aquarius", Vila Isabel, 1981

(Jonas / Lino Roberto / Tião Grande)

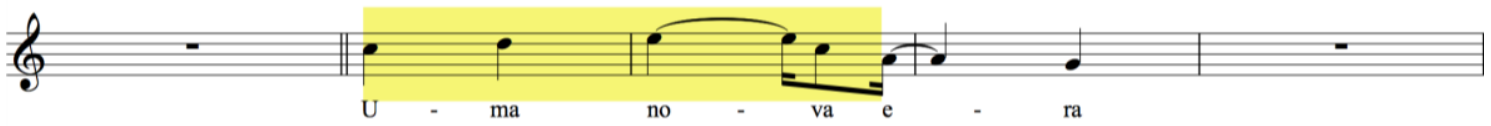

"Se esta terra, se esta terra fosse minha", Vila Isabel, 1990

(Jorge Tropical / Jorginho Pereira / Anninha Guedes / Antônio Grande / Vilani Silva "Bom Bril")

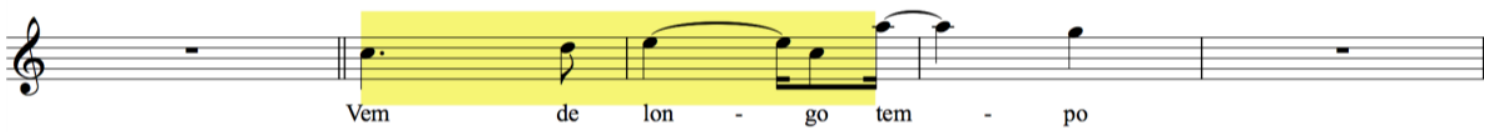

"Lapa em três tempos", Portela, 1971

(Ary do Cavaco / Rubens)

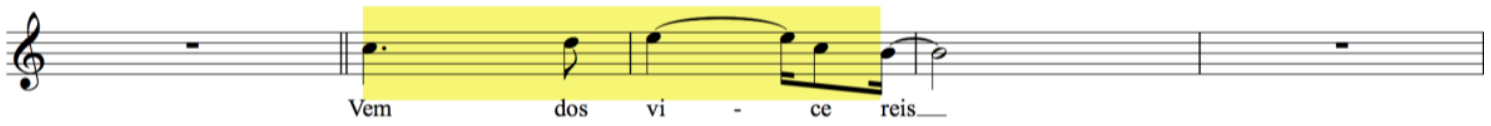

"Das maravilhas do mar fez-se o esplendor de uma noite", Portela, 1981 (David Corrêa / Jorge Macedo)

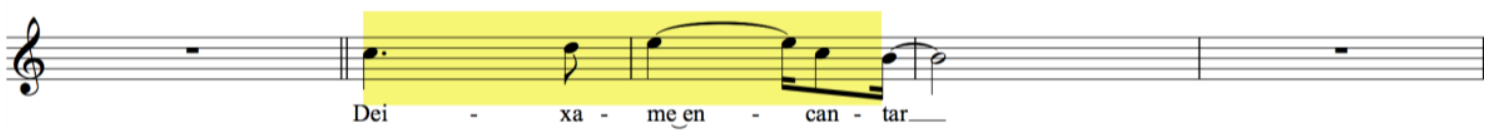

"Ouro escravo", Em Cima da Hora, 1969

(Normi de Freitas / Jair dos Santos)

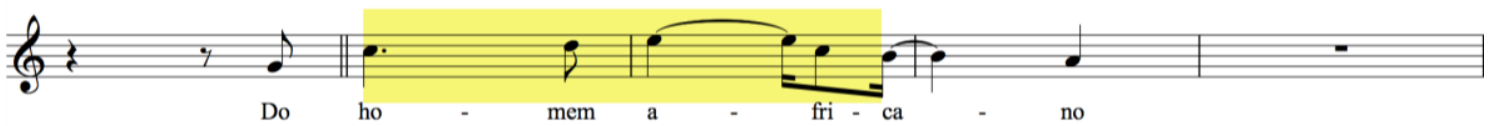

FIGURE 3. Similarities to the first phrase of Macunaíma, herói de nossa gente

(Portela, 1975)

The second phrase (Figure 4) is similar to those found in Cidades feitas de memó rias (Unidos de Lucas, 1975) and Dique, um mar de amor (Vila Isabel, 1978). For phrases from O mundo fantá stico do Virapuru (Mocidade, 1975), G.R.E.S. Saudade (Unidos da Ponte, 1987) and Folia de Reis (Lins Imperial, 1976), the similarity appears mainly in the melodic contour, since the different number of syllables causes some minor rhythmic discrepancies: 
“Macunaima, herói de nossa gente”, Portela, 1975 (David Corrêa / Norival Reis)

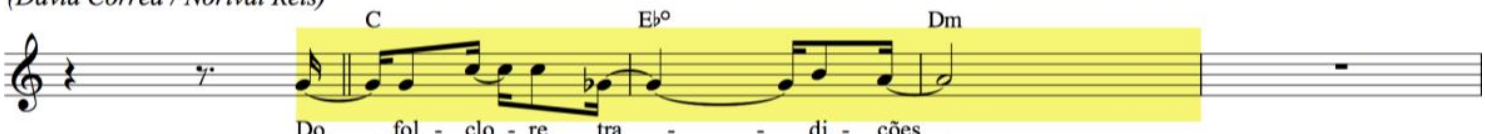

“Cidades feitas de memórias”, Unidos de Lucas, 1975 (Baianinho / Ladyr Goulart / Laci)

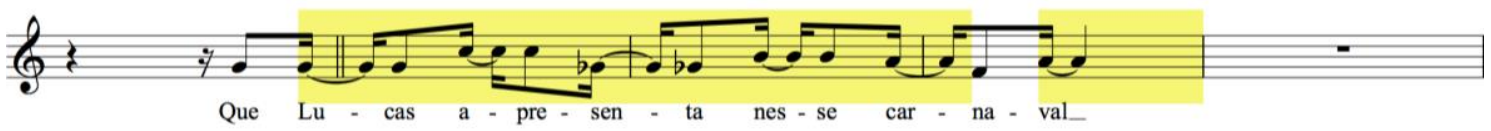

"Dique, um mar de amor", Vila Isabel, 1978

(Jarbas / Garganta de Ferro / Boanezio / Augusto Messias)

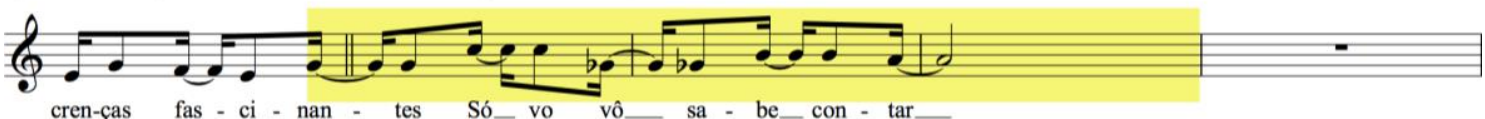

cren-ças fas - ci - nan - tes Só - vo vô_ sa - be - con - tar -

“O mundo fantástico do Uirapuru”, Mocidade, 1975 (Tatu / Nezinho / Campo Grande)

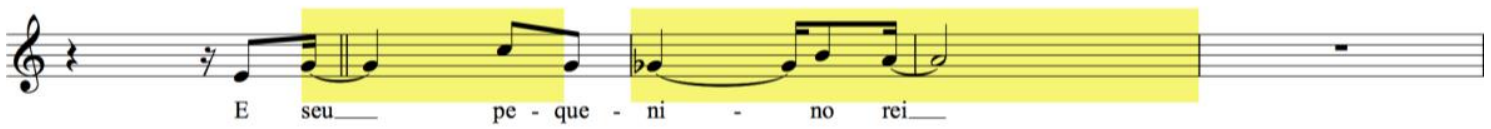

“G.R.E.S. Saudade”, Unidos da Ponte, 1987 (Silvio da Ponte / Zoinho da Ponte)

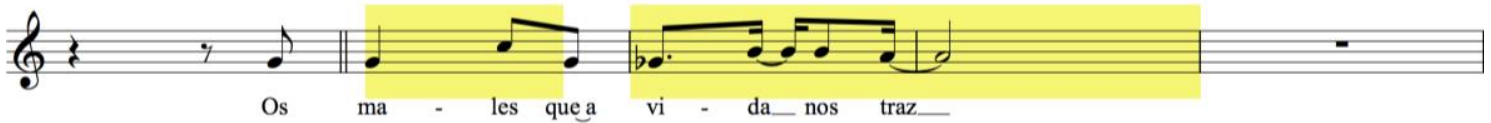

"Folia de Reis", Lins Imperial, 1976 (Agnelo Campos / Efe Alves)

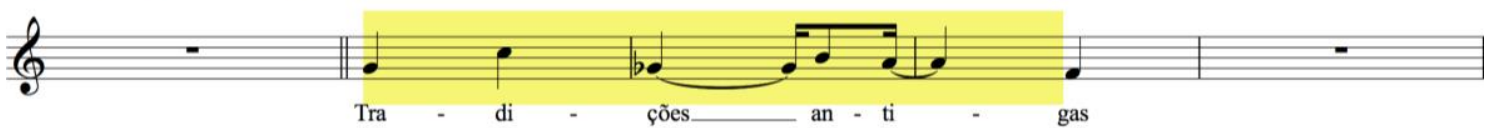

FIGURE 4. Similarities to the second phrase of Macunaíma, herói de nossa gente (Portela, 1975)

The third phrases of Poemas de máscaras e sonhos (União da Ilha, 1976) and Sou amigo do rei (Salgueiro, 1990) are identical to the one from the samba of reference, except for the pick-up bar and slight changes in the rhythm and the ending, whereas in Elis, um trem chamado emoção (Mocidade, 1989) e $A$ União faz a força, com muita energia (União da Ilha, 2001), the 4-3 suspension (C-B) is suppressed as the verse requires it (Figure 5). 
"Macunaíma, herói de nossa gente", Portela, 1975 (David Corrêa / Norival Reis)

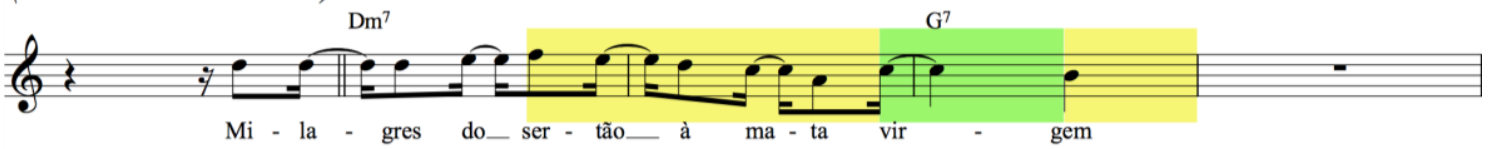

"Poemas de máscaras e sonhos", União da Ilha, 1976

(Da Vala / L. Barbicha / Wilson Jangada / Dito / Mestrinho)

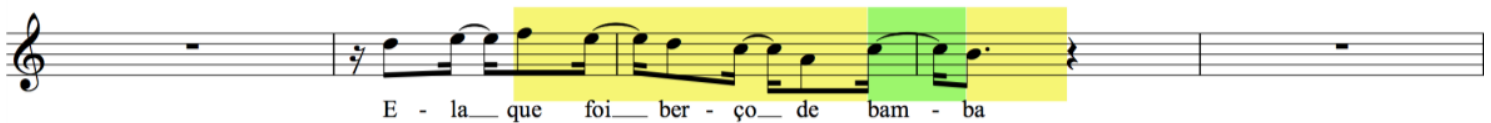

"Sou amigo do rei", Salgueiro, 1990

(Alaor Macedo / Arizão / Demá Chagas / Pedrinho da Flor / Fernando Baster)

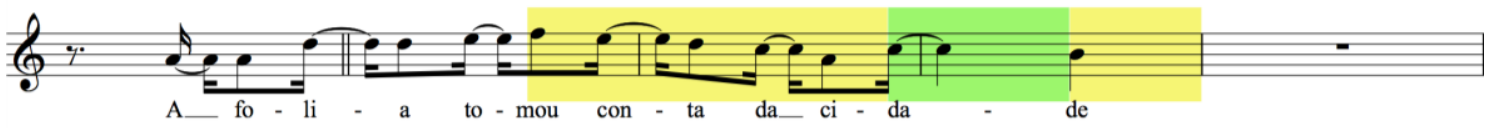

"Elis, um trem chamado emoção", Mocidade, 1989

(Paulinho Mocidade / Dico da Viola / Cadinho)

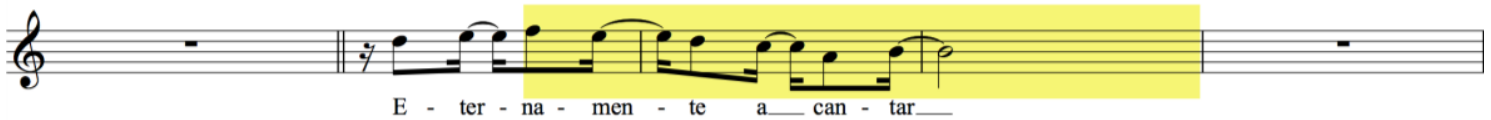

"A União faz a força, com muita energia", União da Ilha, 2001

(Marcio André / Djalma Falcão / Almir da Ilha / Dito)

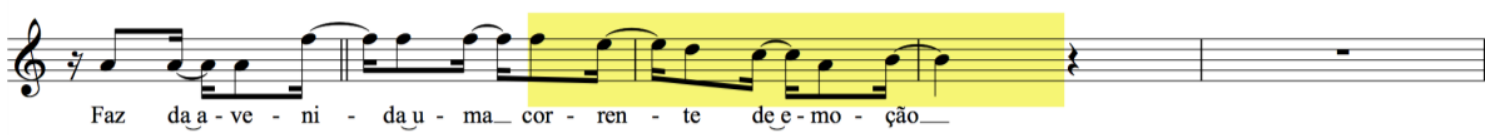

FIGURE 5. Similarities to the third phrase of Macunaima, herói de nossa gente

(Portela, 1975)

Finally, the last phrase appears identically in Se todos fossem iguais a você (Mangueira, 1992), Paraná - Esse estado leva a sério o meu Brasil(Unidos da Ponte, 1995) and Um Rio de mar a mar: do Valongo a glória de São Sebastião (Portela, 2014) (Figure 6):

"Macunaima, herói de nossa gente", Portela, 1975 (David Corrêa / Norival Reis)

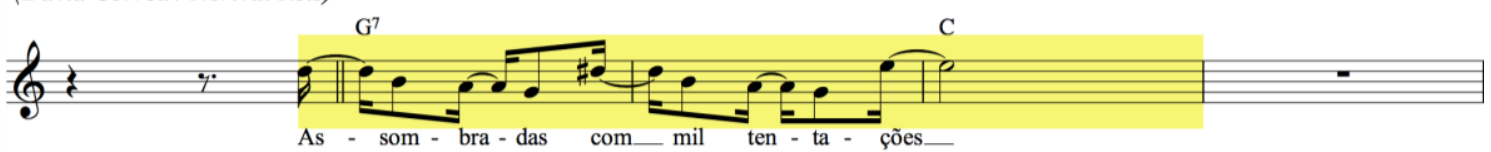

"Se todos fossem iguais a você", Mangueira, 1992 (second part) (Hélio Turco / Alvinho / Jurandir da Mangueira)

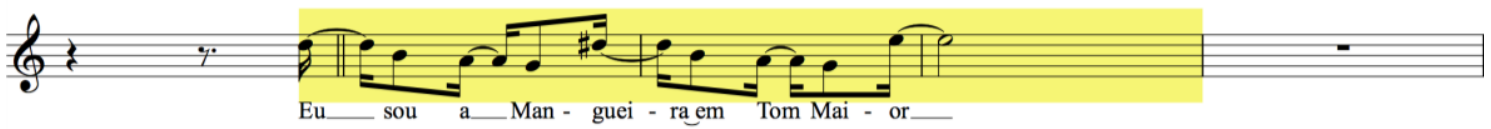

"Paraná - Esse estado leva a sério o meu Brasil", Unidos da Ponte, 1995 (second part) (Wanderley Novidade / Walter Pardal / Walney Rocha)

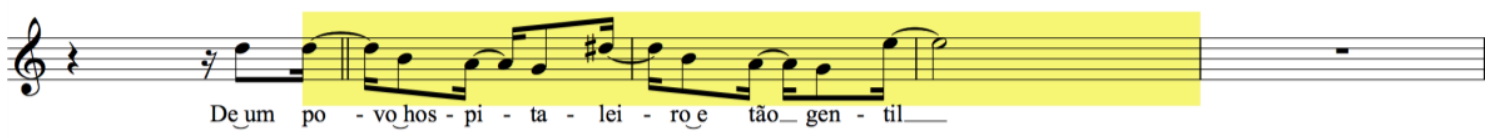

"Um Rio de mar a mar: do Valongo à glória de São Sebastião", Portela, 2014

(Toninho Nascimento / Luiz Carlos Máximo / Waguinho / Edson Alves / J. Amaral)

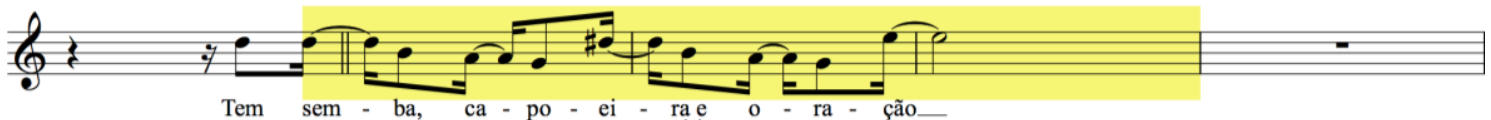

FIGURE 6. Similarities to the fourth phrase of Macunaíma, herói de nossa gente 
(Portela, 1975)

The degree of orality in a culture determines not only the modes of transmission of the discourses in a community, but also the ways originality and innovation are measured. As Lilliestam states,

In Western art aesthetics one of the cornerstones is the idea that a work of art should be original and unique. Creating something on the basis of what someone else has done is not very good, and if the copy is too apparent it is plagiarism, which is even a punishable offence. It is in this view of a musical work as an original creation that we can see one of the more distinct conflicts between the practice of folk and art music, or, put another way, between thinking based in orality and literacy (Lilliestam 1996: 212).

Such vision agrees with the statement of Rachel Valença, who emphasizes that "commonplace" in samba-enredo must be understood in a context in which originality is not the main factor in determining the artistic value of works:

There is a clear behaviour (...) that doesn't oppose creativity to banality, which is contrary, for example, to the modern view of overrating the new, that there must always be a search for new ways of saying things. To the samba-enredo composer, the banal, the trivial, what has been done, has the status of poetic truth (Valença 1983: 142, my translation).

Composers Diego Nicolau and Toninho Nascimento consider the existence of melodic repetitions in samba-enredo as contingencies of composing in that genre:

Like all music genres, there are some characteristics you need to follow in order to make it work. It's that thing: "nothing is created, everything is copied". There are some standards that work, and you need to have them as a parameter (Diego Nicolau 2015, my translation).

When you're going to compose a choro [Brazilian instrumental music genre], you already have a model in you. I don't know how to compose a rock song, for example, because I don't have this model in my mind. When I compose a samba-enredo, I compose with the intention of making a samba-enredo. We have references of what a samba-enredo is, of what a samba de quadra is, so unconsciously these references come in our minds (Toninho Nascimento 2014, my translation).

Although orality is important in understanding samba schools and the values involved in the composing of samba-enredo, it is important to remember that

in the case of samba-enredo, contextual linkages to participatory and community-based music making are, in fact, manifest and highly meaningful, but they are continually challenged and redefined through interaction with commercial and market forces (Moehn 2004: 50-1).

This means that in order to understand the phenomenon of formularity in sambaenredo more broadly, it is necessary to consider another set of factors which, if by themselves do not manage to completely eliminate the consciousness model based on orality present in samba schools, introduce new forces that will tangibly affect sambistas'living experience, and, consequently, their composing process. 


\section{Capitalist Logic}

In 1968, the first official album of the samba schools was released. The recording of samba-enredo albums a few months prior to carnival, along with a greater exposure of the genre through radio broadcasting, brought important changes to the way the samba schools' music was received in the parades:

The greatest hits of samba-enredo were the easiest to memorize. The public, under constant exposure to radio programming, would be able to judge the quality of sambas that would be already out before carnival. It would then initiate a circular process in which the best samba-enredo actually was the most largely broadcast one, and vice-versa (Augras 1998: 85, my translation).

Samba-enredo was, therefore, completely inserted into the cultural industry. In relation to phonographic records, the sales of samba-enredo discs reached their peak in 1986, when more than 1 million copies were sold (Cavalcanti 1995: 85). Although samba-enredo's marketability as carnival music has diminished over the last twenty years, data from Pró-Música Brasil Produtores Fonográficos Associados (formerly Associação Brasileira de Produtores de Discos - ABPD) show that the album Samba de Enredo 2017 was the best-selling album in 2016 (Pró-Música Brasil 2016) (6). Added to radio and TV broadcasting rights and so-called arena rights (7), this represents considerable gains for the composers. Thus, it is possible that many harmonic, melodic and formal repetitions of samba-enredo originated in a pursuit of formulae to hit the market in a process German philosopher Theodor Adorno calls standardization:

The musical standards of popular music were originally developed by a competitive process. As one particular song scored a great success, hundreds of others sprang up imitating the successful one. The most successful hits, types and "ratios" between elements were imitated, and the process culminated in the crystallization of standards (Adorno 2002: 443).

Such a process of standardization has as its corollary what he calls pseudoindividualization: variations only in the superficial aspects of works that would give them an aura of originality while no changes in their structural aspects actually happen. So, in a logic of massified consumption, listeners' demand for both novelty and a sensation of familiarity with the musical object would be supplied.

Diego Nicolau states that the pursuit of success in samba-enredo might result in the deliberate adoption of traits of other songs:

Those are things we learn over time. There's plenty we pick up in the heat of the battle. The parade teaches those who are observant. A composer must get that. It's important that you ask yourself: "which parade really grabbed people this year? We must listen to that samba and see what happened. Why did it happen like that? What worked out well in it?" I'm a very observant guy, one who studies a lot, because I want to win the samba contest. I want to live these emotions every year. I want to look at the crowd and hear everyone singing my samba. I strive for this. I don't do it just for money. Money is nice. It's the consequence of it all. It's my job. But the most important for me is seeing people singing my samba. No money equals that. It's really gratifying. You feel you're important for your school and for carnival. Maybe this is my kind of vanity. My vanity is seeing people singing my samba (Diego Nicolau 2015, my translation). 
The complexity of the economic aspects surrounding samba-enredo is not related solely to its presence in the massive cultural industry in the form of television networks, radio broadcasters and record companies. In the heart of samba schools, a model of socialization different from the oral one described previously has begun to take form.

Before reaching the mainstream, sambas-enredo are presented in an alternative circuit far from the eyes of the large audience. Months before carnival, each school holds internal contests to choose which samba-enredo will be taken to the parade. Dozens of works are entered and, after weeks of competition, the official samba is elected. In this process, each competing partnership must bear the costs of musicians and singers who will play the samba on the quadra (the space where samba school rehearsals are performed), as well as the costs of paid crowds, flags, confetti and all kinds of resources to draw the judges' attention to the song. It is broadly understood that winning an internal contest of a samba school will cost some tens of thousands of reais (Brazilian currency).

Nowadays, if a guy doesn't have much money, he won't compete for sambaenredo, which became a business that depends on the money of the composer. That's why it is common for there to be this author, who, poor soul, sometimes, is not able [to compete] even though he has a beautiful samba. His samba is exquisite, but he can't afford a crowd to fill a hall, or rent a bus, or even pay the samba's admission fee (Tristeza 2009, my translation).

The growth of expenses led to the emergence of the so-called samba offices, groups of composers who have the financial structure to compete in various samba schools. Although the samba offices are viewed negatively by many samba composers, there are others who see this phenomenon in a more pragmatic way:

You can say what you want about us, but we play the game with their rules. We do not play outside the norm. Do we have to bring a crowd? There will be a crowd. Do we have to bring people? So we'll bring people. Do we have to bring a good singer? I'll take the best. I' $m$ in the game. (...) Do we have to buy a VIP area? I'm going to buy it. I will not let someone buy it before me (Diniz 2013, my translation).

Hence the importance of financiers comes up, those whose responsibility in these partnerships is not composing samba but dealing with the financial costs of the contest. Composer Toninho Nascimento even states that nowadays financers have a prominent role in the economic gearing of samba schools:

You've got to understand that a samba-enredo contest is a spectacle that precedes the major spectacle which is the parade. And every musical spectacle needs a sponsor. There's no theatrical play without a sponsor, there's no musical event without a sponsor. There must be a sponsor. If there isn't one, it won't work. So, a samba-enredo contest can also be taken as a spectacle. It needs a sponsor (Toninho Nascimento 2014, my translation).

Thus, out of the economic influence of financiers, a new job appeared specially for samba contests:

Now there are cheering professionals. We've reached that point. It's a guy you hire, he earns a salary to bring cheering supporters together. "Look, you give me R\$1500. From this, I'Il make a barbecue with beers and I'Il take my money. 
Then I'Il bring you a bus with up to seventy people to sing along with your samba". And you've got to do that, because it won't work otherwise. (Diego Nicolau 2015, my translation)

So, with these supporters the directors of the samba schools can, at least theoretically, foresee how the samba itself will be received in the parade:

You've got a better samba than mine. But then you bring twenty people to sing along and I bring 250 . Those 250 will bring a quality to my samba that it doesn't have. A social fact is created that is going to have effect over the people in that environment. So nowadays you need cheering supporters (Toninho Nascimento 2014, my translation).

Furthermore, there is another more practical reason: samba schools use the sambaenredo contests to raise funds. So, it is essential that the partnership corresponds to the samba school's expectations not only in relation to musical aspects but also, or mainly, in relation to finance.

Things have changed and the samba-enredo contest is no longer restricted to being there and listening to the samba. You want something else. This has reached the point that sometimes a samba is very good and people still say: "your samba is very good, but you're not bringing people to the quadra". In other words, they're saying "either you bring people or you won't win" (Professor 2015, my translation).

It is important to observe there is a code of ethics that prevents a composer from signing sambas for schools belonging to the same group (8), which often causes the real composer not to be named in the partnership:

Is there any written prohibition to it? No, I don't think so. But it's common sense. Especially in the Special League [the group of the biggest samba schools]. In the Access League [the group immediately below], some people write their full name and there's no problem at all, perhaps because there are so many schools there. But in the Special League people won't put up with it like that. (...) That's the kind of thing that gets your samba disqualified (Diego Nicolau 2015, my translation).

Such a code of ethics may be a manifestation of what Franco Fabbri (1982) calls "ideological concealment". Thus, one of the ideological rules in the universe of samba schools is that the composer must emanate an aura of loyalty to his/her school. As Diego Nicolau states, "a samba school supporter wants all those representing his school to represent only his school. I think that's why the matter [of publicly signing sambas in several schools] is not ethically liberated" (Diego Nicolau 2015, my translation).

In an interview, I asked whether Nicolau resented not having his name in the official credits of a samba he had composed but not signed:

No. Not at all. There's not even an itch. There's no reason why, because my partners never made a secret of it. Perhaps if they did, that would bother me, but I would not be bothered even so, I guess. It's nice anytime I can have my name there, but if due to circumstances I can't, that doesn't hurt me as a composer. It hurts some people, though: "No, I don't write a samba I won't sign, I'd rather not write at all". In my case, I'd rather do it. Because I like 
composing samba, I like being with my friends, I like the process, I like meeting, I like going wild, the whole process of making samba is so seducing to me (Diego Nicolau 2015, my translation).

André Diniz thinks likewise:

If I accept the idea of not signing, it wouldn't be honest to say later that something is mine. Maybe that isn't that fine, but I don't know if it's that bad either. I simply don't mind (...) for sake of my composition during the contest (Diniz 2013, my translation).

However, even if a sambista composes for several schools, they generally have a personal preference for the one where their career in samba started. André Diniz, for instance, states that he gives much more of himself when composing for Unidos de Vila Isabel than for any other school:

You just can't compare. It's the professional against the passional, the love, the mad passion. (...) So, it's wonderful composing [for other schools], but at Vila... [it's different]. And there's this kind of thing, too, you've got five sambas to write, then a wonderful melody pops up. Then I say, "no, no, no, they won't have this one! This one is for Vila!" [laughs] (Diniz 2013, my translation).

It is therefore clear that the composers' wing as an institution of acquisition of lore, reverence to tradition, and respect as a sambista, doesn't exist anymore. Tuninho Professor regrets that things have reached this point, but considers it necessary to accept the situation:

The composers' wing needs to be respected, needs to be preserved. There are some elderly people in it that gave their best years to samba and are proud to stand for their school and say "I'm from Imperatriz Leopoldinense, I'm from Mangueira [samba school], I'm from Salgueiro [samba school]". So, the composers' wing lost its essence a bit. But then we have to understand the other side of it. The professionalization of samba, the modernity, also impelled composers to claim their place in the sun. So now, unfortunately, a composer won't stick to a single school, he wants to make his own money, so he goes to this school, and then to that one... In a nutshell, I'm not an adversary to whoever does it (Professor 2015, my translation).

Most composers admit that within such a model of samba contests, the best samba is not always chosen for the parade:

Rarely the current year's samba sticks in people's memory. Out of us, the older sambistas, I'm the only one still trying, I guess. Most of us have given up competing, because it's an extremely unequal contest. Because you have to hire buses, you have to buy rounds of drinks, you have to have barbecue parties, you have to pay for entry tickets, you have to gather crowds (...) it's so much that you even need a sponsor. There are sponsors for samba-enredo now. That's when you throw quality out of the window. Because that's nothing about samba, that's like lab freaks (Portela 2009, my translation).

I don't speak against it, because it's not an illegal thing - LIESA [Independent League of Samba Schools of Rio de Janeiro, the main association of the samba schools] doesn't prevent it, you can sign as many sambas in your name as you like - and it's not immoral, because it's your work and you're making money 
with it. For me, it's just a cultural thing. Because it's banalizing, you then discredit the value of a music style. You're then making it hollow, you're killing it (Toninho Nascimento 2014, my translation).

Finally, the high costs of the contests, together with the problem of adapting to the new aesthetics of samba-enredo, ended up excluding the more experienced composers:

Most won't compete anymore, many just give up. Because long before [the finals] there are already rumours of a samba being the decided winner. It's disheartening. (...) Some composers simply don't believe [that there are some marked cards] and keep on [in the contest] but some others have already given in. Some are still hopeful: "I don't think so, I still think we're pure", and keep on in the competition. Because it's also a hobby, an addiction (...) as well as hope (Corrêa 2013, my translation).

\section{Conclusion}

We've seen in this article that orality is not only related to modes of transmission but also, and mainly, to models of thinking that ultimately define the importance of originality in a repertoire. From the statements of sambistas, we've found, on the one hand, samba-enredo composers who do not necessarily frown upon similarity between their works and others, considering it as a contingency of composing within the limits of this genre. On the other hand, every samba composer refuses to be taken as a plagiarist even though in samba it is hard to define the boundaries between the action of memory, tradition, style restrictions and deliberate copying. The line between these two attitudes, intentional or unconscious copying, is perhaps one of the most inscrutable aspects of the music of samba schools; at the same time, this hypothetical line constitutes the main controversy among sambistas themselves when defining what may be considered tradition or standardization in samba-enredo.

We've also verified that, more recently, many of the aspects concerning orality have disappeared in samba schools, notably the composers' wing, giving way to a capitalistic logic that, most notably, has made composers search for traditional ways of commercialization and distribution of music, such as releasing recordings and broadcasting on radio and TV. In addition, the emergence within samba schools of a problematic format of samba-enredo contests has ended up both ostracizing the elder composers and inhibiting the participation of novices.

Furthermore, we cannot ignore the interactions between the poles of orality and capitalistic logic, exemplified by the case of the samba schools' official albums. The basic motivation of the recording is to obtain profits for the record companies and the samba schools. However, this practice gives rise, and here we have another contradiction, to a well-documented repository of sambas that makes it possible for successive generations of composers to have a vast and profound knowledge of the tradition that precedes them. The statement of the composer Diego Nicolau is revealing:

My learning was all by discs. I have LPs, I have all the CDs. I was always in love with samba-enredo. I was a kid who loved samba-enredo. When I got the taste for it, I went to search for older sambas (Diego Nicolau 2015, my translation). 
Evaluating the role of orality and capitalistic logic in samba schools is, therefore, a task of enormous complexity for the analyst. I have aimed to demonstrate, though, beyond creating a mere taxonomy, that the study of samba-enredo formulae can concretely reveal the action of both these poles in the sambistas' composing process.

\section{Endnotes}

(1) This article is an expanded and revised version of the paper The Music of the Samba Schools: A Challenge for Popular Music Studies (Prado 2017), presented at the XIX IASPM Conference (Kassel, Germany) and published in its proceedings.

(2) A composer's lack of technical training at times called for the presence of another character: a partner instrumentalist, whose job was revising the samba, altering it if necessary and passing it to other musicians.

(3) Ivan Vilela calls this "the triumph of ignorance", the great creative capacity of an uneducated person, which has been responsible for "the diversity and exceptional quality of our popular music" (Vilela 2013: 70).

(4) The main difference between samba-enredo and samba de quadra (also known as samba de terreiro) is that the former is composed specially for the parade, based on the plot (enredo) presented by the samba school. The latter can be composed all through the year and one can sing about "life experiences, love, fights, parties, nature and the praise for his school and samba itself" (Nogueira 2005: 10, my translation). In addition, sambaenredo is often longer than sambas de quadra.

(5) In the following examples, organized in paradigms, the elements highlighted in yellow correspond to what Simha Arom, in a private conversation during my research stage in France, suggested naming as "anchor point", which is the feature in common between the sambas. What is not highlighted corresponds to the "substitution point", the element of variation. Finally, the elements highlighted in green correspond to variants that do not alter at all the character of the anchor point. On the notion of paradigm in music, see Arom (2001).

(6) This very same report by Pró-Música shows that digital copies (streaming, downloads) accounted for the largest share $(49 \%)$ of Brazilian musical market revenue, greatly surpassing physical copies (14\%; the remainder accounting for public performances and musical synchronization of tracks in audiovisual media and advertising). At the same time, there is not one samba-enredo track among the 40 most streamed songs in 2016. Therefore, one of the reasons for such good market performance of samba-enredo official recordings may be not necessarily its popularity among a large audience, but the fact that a great deal of samba-enredo aficionados insist on buying the officially released discs from physical and online stores or disc launch parties promoted by the samba schools.

(7) Arena rights are those related to "persons' or larger groups of people's images in collectively attended spectacles" (Prestes Filho 2009: 75, my translation) such as samba schools' parades. Toninho Nascimento discloses the ways a samba-enredo composer's wages are constituted: "a samba-enredo composer has three sources of revenue: copyrights over performance, recordings sales and arena rights. Since samba-enredo tracks are barely broadcast on the radio nowadays, and recordings sales are too low, the arena right is a greater source of revenue" (Toninho Nascimento 2014, my translation).

(8) The parades of the samba schools are divided into groups, in which the worst placed of a certain group is replaced by the best placed of the group immediately below. 


\section{Acknowledgements}

I would like to thank Fundação de Amparo à Pesquisa do Estado de São Paulo (FAPESP) for the financial support (process number 14/27355-6) of my doctoral thesis (Souza 2018), on which this article is based.

\section{References}

\section{Bibliography}

Adorno, Theodor. 2002. Essays on music. Selected, with Introduction, Commentary, and Notes by Richard Leppert. New translations by Susan H. Gillespie. Berkeley, Los Angeles, London: University of California Press.

Almada, Carlos. 2012. Harmonia funcional. Campinas: Editora da Unicamp.

Arom, Simha. 2001. Modelización y modelos en las músicas de tradición oral. In F. Cruces Ed. Las culturas musicales: lecturas de etnomusicologia. Madrid: Trotta: 203-232.

Augras, Monique. 1993. A Ordem Na Desordem: A regulamentação do desfile das escolas de Samba e a exigência de 'motivos nacionais'. Revista Brasileira de Ciências Sociais 8 (2): 90-103.

Azevedo, Ricardo. 2013. Abençoado \& danado do samba: um estudo sobre o discurso popular. São Paulo: EDUSP.

Cavalcanti, Maria Laura Viveiros de Castro. 1995. Carnaval carioca: dos bastidores ao desfile. Rio de Janeiro: UFRJ/Funarte.

Fabbri, Franco. 1982. A theory of musical genres: two applications. In D. Horn and P. Tagg Eds. Popular Music Perspectives. Gothenburg and Exeter: IASPM: 52-81.

Green, Lucy. 2001. How Popular Musicians Learn: A Way Ahead for Music Education. Aldershot: Ashgate.

Lilliestam, Lars. 1996. On Playing by Ear. Popular Music 15 (2): 195-216.

Moehn, Frederick. 2004. "The Disc is Not the Avenue": Schismogenetic Mimesis in Samba Recording. In P. Greene and T. Porcello Eds. Wired for Sound: Engineering and Technologies in Sonic Cultures. Middletown: Wesleyan University Press: 47-83.

Nogueira, Nilcemar. 2005. Dossiê das matrizes do samba no Rio de Janeiro: Partido-alto, samba de terreiro, samba-enredo. Brasília: Iphan.

Ong, Walter. 2002. Orality and Literacy: The Technologizing of the World. New York: Routledge.

Prado, Yuri. 2017. The Music of the Samba Schools: A Challenge for Popular Music Studies. In J. Merrill Ed. Popular Music Studies Today: Proceedings of the International Association for the Study of Popular Music 2017. Wiesbaden: Springer Vs: 253-260.

Prestes Filho, Luiz Carlos. 2009. Cadeia produtiva da economia do carnaval. Rio de Janeiro: E-papers.

Pró-Música Brasil. 2017. Mercado fonográfico mundial e brasileiro em 2016. https://pro-musicabr.org.br/wp-content/uploads/2017/05/Mercado-deM\%C3\%BAsica-Global-e-Brasileiro-em-2016-FINAL.pdf. Accessed: 5 January 2018.

Rawlins, Robert and Bahha, Nor Eddine. 2005. Jazzology: The Encyclopedia of Jazz Theory for A/l Musicians. Milwaukee: Hal Leonard. 
Souza, Yuri Prado Brandão de. 2018. Estruturas musicais do samba-enredo. Doctoral Thesis. Escola de Comunicações e Artes, Universidade de São Paulo, São Paulo.

Ulhôa, Martha Tupinambá de. 2008. Perdão, Emília! Transmissão oral e aural na canção popular. In Matos, Cláudia et al. Eds. Palavra cantada: ensaios sobre poesia, música e voz. Rio de Janeiro: 7 Letras: 249-267.

Valença, Rachel. 1983. Palavras de purpurina: estudo linguístico do samba-enredo. Master Dissertation. Instituto de Letras, Universidade Federal Fluminense (UFF), Niterói.

\section{Videography}

Corrêa, David. 2013. Memória das Matrizes do Samba no Rio de Janeiro. Interviewed by Aloy Jupiara and Rachel Valença. Museu do Samba (Centro Cultural Cartola).

Diniz, André. 2013. Memória das Matrizes do Samba no Rio de Janeiro. Interviewed by Aloy Jupiara and Rachel Valença. Museu do Samba (Centro Cultural Cartola).

Guga. 2013. Memória das Matrizes do Samba no Rio de Janeiro. Interviewed by Aloy Jupiara. Museu do Samba (Centro Cultural Cartola).

Katimba, Zé. 2009. Memó ria das Matrizes do Samba no Rio de Janeiro. Interviewed by Aloy Jupiara. Museu do Samba (Centro Cultural Cartola).

Paula, Edeor de. 2009. Memória das Matrizes do Samba no Rio de Janeiro. Interviewed by Aloy Jupiara. Museu do Samba (Centro Cultural Cartola).

Portela, Noca da. 2009. Memória das Matrizes do Samba no Rio de Janeiro. Interviewed by Aloy Jupiara. Museu do Samba (Centro Cultural Cartola).

Professor, Tuninho. 2015. Memória das Matrizes do Samba no Rio de Janeiro. Interviewed by Aloy Jupiara and Rachel Valença. Museu do Samba (Centro Cultural Cartola).

Sabiá, Djalma. 2009. Memória das Matrizes do Samba no Rio de Janeiro. Interviewed by Aloy Jupiara. Museu do Samba (Centro Cultural Cartola).

Tristeza, Niltinho. 2009. Memória das Matrizes do Samba no Rio de Janeiro. Interviewed by Aloy Jupiara. Museu do Samba (Centro Cultural Cartola).

\section{Interviews}

Diego Nicolau. 2015. Interviewed by Yuri Prado, Rio de Janeiro, 1 April.

Martinho Da Vila. 2014. Interviewed by Yuri Prado (telephone), 18 August.

Toninho Nascimento. 2014. Interviewed by Yuri Prado, Rio de Janeiro, 4 February. 